\title{
Community Literacy: Commodifying Children's Spaces
}

Linda Wason-Ellam and Angela Ward with Cynthia Fey, Anna-Leah King, Brenda Gilchrist, and Lynne Townsend

Across families of many cultures, literacy is used in a wide variety of ways. Literacy is described as a set of social and cultural practices, not simply a skill learned through formal schooling and detached from other social constructs (Street, 1984, 1995). Family life is a distinct domain for literacy that is intricately woven into the everyday stream of activities where the purposes, values, and the roles families take may differ from the cultural capital required by the formal literacy that children need for success in schooling (Gates, 1997; Heath, 1983; Hicks, 2000; Purcell-Taylor \& Dorsey-Gaines, 1988; Valdés, 1996; Wason-Ellam, 2001), a space outside of the private, vernacular literacies of family and the community. Although literacy learning occurs in the family's immediate environment, it cannot be considered apart from the community spaces that connect the family across boundaries or the overlapping social world of relationships and texts that are embedded within the community (Moje, 2000). Community literacy appears to be a complex and dynamic dimension comprising a family's social, geographical, and economic spaces and the extent to which those spaces may be affected by the family members' access to services, resources, and information. Other researchers expand the notion of literacy in community spaces as focusing on the social and cultural capital that literacy affords (Bourdieu, 1986), the funds of knowledge that families possess (Moll, 1992), the community influences, (Neuman \& Celano, 2001) or the vernacular literacies, that is, the household-centered social networks across which families share resources, skills, and local knowledge that are articulated in the community (Barton \& Hamilton, 1998). In this sense, 
community literacies are the local and the globally situated practices that become the building blocks of learning as they underpin and support the more valued literacies that schools teach.

Often, community literacy is described as reading documents such as signs, notices, posters, advertisements, letters, or schedules of recreational activities. Or it may be the reading practice associated with participation in neighborhood activities or cultural events in libraries, book stores, and childcare centers. Embedded within these intersecting practices are opportunities for children to learn and develop through observation and apprenticeship (Lave \& Wenger, 1991) as they see others within the community use reading and writing in their daily lives for a variety of purposes. At present, what community literacy research may not make explicit is changing layers of literacy located in the "kid networks" (Nespor, 1997) or child-centred spaces. These layers of literacy and layers of community serve as a powerful role in children's learning and are articulated through a variety of interactive linkages. The layers flourish in the decontextualized spaces found in representations (books, games, leisure activities) and the virtual spaces transmitted through technologies (television, films, computers, and videos). Whether shopping in the community or watching television, children access layers of literacy globally from media spaces often embodied with inanimate elements. Sometimes it may be a book linked to a television show such as Dora the Explorer, a media character toy from the Disney movie, Finding Nemo, or a Nintendo game, Super Mario that connects the child to a virtual reality. From this perspective, the question to ask about community literacy practices is how do children engage in social and cultural activities that involve texts that are spread across mass distributed images or representational spaces (Nespor, 1997, p. 169) within virtual communities and readily become integral to home literacy practices? 
In this paper, a team of educator-researchers describe their documentation of the multiliterate experiences that were accessible to young learners in an ethnically diverse neighbourhood in a Canadian prairie city ${ }^{1}$. We identified the availability of cultural and linguistic resources that acknowledge their situated nature in social practices and offer the possibility of representing the multiple literacies and the multi modal ways of learning which exist in any culture. In our research, we noted that community literacy might be best defined not only in terms of the conventional ways of using print but moreover in the intertextuality of imageries, texts, and artifacts of electronic technologies that coexist. Electronic technologies have a powerful impact upon literacy learning in and out of school. This shift more accurately views children in terms of the individual differences, knowledge and skills, that is, the available discourses, language, and practices that children have had access to and practice within their communities.

As a research team, working within urban communities for many years, we were intrigued with teachers' comments that children were coming to school without a place for reading in their lives or a storehouse of classic children's stories that served as models for their writing. In our conversations with teachers, they told us that children in this neighbourhood were more likely to have read books about Pokémon or Barney, the popular TV dinosaur, than to be familiar with the traditional stories and nursery rhymes such as The Gingerbread Boy or Goldilocks and the Three Bears. Teachers told us that children lacked both interest in and knowledge of writing based upon literary borrowings such as simple story structure or the words, phrases, patterns and conventions of text. Reading and writing are intertwined. The development of the writing does not reside in writing alone, but requires reading and being read to (Smith, 1988). As educators, parents, and grandparents, our research team began to question the role of reading in community literacy practices. 
From teachers' comments about children's dwindling interests in reading and writing the overarching research focus emerged. To answer this question, a cross-cultural and intergenerational team used a multi-site approach to observe community literacy practices demographically and linguistically. Rather than "hanging out" in the school, we observed within homes and the community to view critically the social practices in which children encounter possibilities for literacy learning and the spatial practices, the activities through which spaces are experiences. Additionally, we collected samples of the layered texts within the neighbourhood spaces in order to interpret the multiple pathways that young children might take in joining a community of readers. We watched children's televisions programs and regularly participated in websites such as the PBS Kids featuring Calliou, Between the Lions, and Zoomboomafoo. We played the media games, viewed the stories and downloaded the activities to print. Furthermore, we engaged in conversational interviews with over 100 parents, grandparents, teachers, children, librarians and shopkeepers to understand how children were using literacy in their lives out of school. In this paper, we open new conversations about literacy resources that extend beyond the boundaries of the local geographical space. We describe community literacy as rapidly becoming a complex commercial network that was situated both in the immediate spaces and within the virtual spaces of a global world. From this position, we viewed print and electronic technologies as enabling children, with a click of a mouse, channel selector, or joystick, to access literacy communities across space and time. Extending upon Furman's (1998) metaphor for a community which is characterized as an "interconnected, interdependent web of persons engaged in global community" (p. 312), we suggest that community literacy might also be in a constant state of renewal and flux in the social sites of everyday life. 


\section{Finding a Stance}

In a naturalistic study, Linda and Angela collaboratively explored the community literacy of an urban neighbourhood, Westside Park. We brought many years of teaching and researching to the local cross-cultural schools. Like Hicks (2000), we held the belief that critical to the research was an expanse of "lived time" or historicity doing field work in urban neighborhoods enabling us to understand, respect, and interpret the literacy lives of children and families while advocating for social change. Collaborating with us on the research study were four graduate students giving the team an intercultural mix. Cynthia and Anna-Leah had experiences working or living in urban Aboriginal communities, which permitted them to adopt a local frame of reference. In their roles of mothers to young children, they offered valuable insights into the contemporary kid networks during the initial phase of the study. Later, Brenda, who is both a school administrator and mother of teens and Lynne who had extensive research experience with local community organizations for young children, joined the project bringing new perspectives to the team. As collaborators, we shared research tasks cooperatively and met weekly to dialogue reflectively in lively conversations about our unfolding data.

The study took place in Westside Park, a working class neighborhood in a Canadian city. The community, which was several miles from the city centre, bordered a rapidly growing business district to the west and an expanse of undeveloped prairie to the north. Nested in a criscross web of streets was a school neighborhood whose population reflected the fabric of contemporary society, a mixture of Aboriginals, newly arrived immigrants and refugees from Eastern Europe, Asia, Central America, and Africa dwelling side by side with long time residents. Anchoring the area was the sprawling shopping mall, a "built community," which was a shopping haven for preassembled dreams, as residents frequented Wal-Mart, a one-stop- 
shopping-extravaganza or the Superstore, a grocery and sundries warehouse. Huddled beside the anchor stores were an assemblage of buildings hinged together like dominoes that beckoned customers to donut shops, fast food outlets, pet emporiums, clothing depots, video stores, a second-hand book store, and assorted services which was located several miles from the city's downtown. With a recent economic downturn, the mall downsized and the only book store, a member of a local chain, closed its operations. The closing became significant to the study as the move left Wal-Mart as the major purveyor to the literacy under 10" market making available its stock of children's pictures books (i.e., Blues Clues, Barney, Pokémon, Barbie, Monsters, Inc.) recognizably linked to the media culture. As one glances at the mall with its familiar signs and logos, it became readily apparent that this could be anywhere in the Americas.

The city straddles the banks of a wide river, which meanders through the downtown core following the natural contours of the land. This same river divides the city into districts of working class, ethnic enclaves, and urban professionals. Like other neighbourhoods on the edge of the city, Westside Park did not evolve over time but was built as a suburban cluster for the distribution of goods and services situated at the neighbouring mall. The hubbub of the mall culture was characterized by aesthetically displayed goods and aggressive commercial signs, as well as enticing "in your gaze" choices of goods that beckoned shoppers. Sometimes residents could be seen hazardly pushing shopping carts laden with bundles along the busy main roads. There were no serviced sidewalks that linked and networked the shopping centre or the libraryleisure centre to the houses or rental apartments, home to many of the cities' new refugees, immigrants, and urban Aboriginals. Access to the local library meant families had to find transportation. As a built community, the loss of neighbourliness or connectedness was apparent. In exploring how the geographical spaces affect community, we rarely noted families 
strolling along the sidewalks, gathering in the neighbourhood or visiting the local parks and playgrounds. To us, it was not a community where a passing motorist might see a snowman in the front yard or children playing in the autumn leaves. Safety is a problematic in city neighbourhoods. Parents told us that they did not send their children out to playgrounds alone. We concur with Scott-Jones (1995) who believes that "demands placed on families by the need to monitor their children's activities in the interest of safety may take time away from other family activities that might contribute directly to the acquisition of academic skills" (p. 93).

Occupying the area, were two elementary schools, one in the Catholic district (publicly funded) and one in the public system. Both schools were large (more than 500 students) and their sprawling configuration shaped the environments for learning activities or spatial practices. Although the schools offered many after-school programs such as art and craft activities, cooking, and gymnastics, it was ice hockey and soccer that were the most popular.

\section{Documenting Community Literacy}

During our three-year study, we recorded in detail the literacies used by community members in the public domains. Inspired by the work of Barton and Hamilton (1998) and Neuman and Celano (2001), the initial stage of the research had been to map the community literacy by gathering documents such as newsletters, flyers, posters, notices, announcements, maps, recreational guides and photos of signs and logos. Later, we inventoried books and other textual materials arrayed in local big-box stores or at second hand vendors, libraries, preschools, and the leisure centre to determine the availability of print in the community. As we canvassed the community and the spatial practices, we began to ask ourselves some critical questions about literacy. Were books and other literacy materials easily and equally accessible to all children and families? Who supplied the literacy resources and for what purpose? Since there was no 
children's bookstore in the shopping centre, nor one within a seven-mile radius, we wondered if this meant that quality literature expressly written for children was not as readily accessible as in other more affluent neighbourhoods on the other side of the river? If not, how did children access reading resources in the Westside Park community?

When looking for a unifying perspective, we began to untangle the initial findings that illustrate that increasingly, getting a child ready for school literacy and getting a child through school literacy was becoming both a commodified and institutionalized business. Commodified meant that literacy was prepackaged and sold as a product; institutionalized was the sense that the global publishers of literacy products were the experts that gave advice and tools to parents about autonomous literacy practices. In describing the layers of literacies in the kid's networks (Nespor, 1997), we found that these commodified resources of cultural practice were the intersections of participation and membership in particular communities of practice, not of simple individual difference. Although family and community literacy practices typically eschew formal teaching, structure permeated many aspects of children's literate life. Technology was used as a curriculum that defined learning not as a tool. From interviews we learned that Westside Park parents perceived that getting young children ready for school made the purchase of a work book series, levelled books, computer games, or videos necessary to learn "bits" of literacy skills. Street and Street (1991) calls this structure the pedagogization of literacy, which is a school-like-literacy practice used outside of school settings in the furtherance of literacy development.

Visits to the neighbourhood library revealed that although library-centered learning provided a bibliographic approach to knowledge, giving a reader access to the widest possible range of literature in the subject (Schuster, 1977), the neighbourhood library was changing to include both 
formal and informal resources. Added to the children's book corner were leveled reading series intended to match easy-books with beginning or novice readers. Prominently displayed in eyelevel shelves were book series such as Road to Reading (published by Little Golden Books Family Entertainment, Inc.) or All Aboard to Reading. These books were characterized by a simple story line and lots of repetitions framed in a phonics-based pedagogy similar to sequential basal readers. In our opinion, the emphasis of these books was the teaching of formal reading skills comparable to those presented in standardized tests. Learning to read was to identify the words correctly rather than to develop enthusiastic life-long readers matched with quality children's books. Although the context of these books drew from literature, the stories were significantly abridged or orthographically altered to short decodable sentences. What seemed to be missing in these books was the fine writing that offers many layers of understanding and its inherent imaginative and artistic qualities. Quality literature for any age is about words chosen with skill and artistry to give readers pleasure (Nodelman \& Reimer, 2003), to open new horizons, and to help them understand themselves and the lives of others. In quality literature, the story can stand on its own while in packaged reading the books are more concerned with teaching skills than with presenting memorable stories (Petersen \& Eeds, 1990).

Our interviews with over 50 families in Westside Park revealed that most had adopted a pedagogized view of literacy which was reinforced through newspaper discussions about literacy issues, labeling on technologies and toys directed towards educational achievement and in the political debates as viewed on talk shows. They sought leveled books as home teaching resources for their children. Many parents were bound in their teaching practices with the memories of the ways they were taught reading (Taylor, 1983) with book formats like Dick and Jane. Parents talked about their children as readers by describing the levels attained and were 
quick to tell us whether their child was reading above or below grade level. Ellen explained her daughter's reading development as participating in the achievement culture. "We bought a lot of books that mark the reading level. That was really helpful I think in her progress to keep track of the levels." Parents' comments such as "I bought Road to Reading so that my child could do better on reading tests," or "I used the printables on the web site so my children could figure out how to do workbooks and get all the requirements needed, " filled our field journals.

In the library's book corner the leveled or graded books were characterized in this way:

- Most books had overtones of being of educational value. Reading skills, levels or grade levels were clearly labeled and explained to parents.

- Books beckoned children "to join in the fun" rather than promoting reading a good story.

- Books had an emphasis on cartooning as the medium of illustration in contrast to the varied and detailed illustrations in quality children's literature.

- The plots focused on action rather than on description or characters' thoughts, values, or motivations.

- Many books were linked to the media culture which had high definition back stories or an established personality profile (Kline, 1993, p. 170) which were limited scripts that were associated with character toys (e.g., Winnie the Pooh, Little Mermaid, Franklin, Thomas the Train, Bob the Builder, or Barbie).

- Books were usually in series that encouraged a sense of collectible ownership as in Mary Kate and Ashley, Goosebumps, Lemony Snicket, or Harry Potter books or with media merchandise. Accordingly, children gain status with peers when they chat about or collect books from popular series (Nodelman \& Reimer, 2003, p. 119). 
In addition, the library displayed a large selection of videos, adapted from traditional children's literature, packaged as self-directed teaching of reading skills. One of the most popular videos was The Sad Dad, from The Between the Lion series. The leveled video was a retelling of Margot Zemach's It Could Always be Worse (1976), a classic Jewish folktale of a poor farmer whose house is overcrowded with his animals. The animated story was rewritten without attention to a writerly quality in order to teach the short a sound, by repeating words such as mad, sad, bad, and dad. Some of words used such as paired rhymes like brag and drag and bare and dare were not age appropriate as they had connotations to the rock star world. The fragmented story was an endless flow of flashing words, unrelated sequences, and images synchronized to rock music. Since the story was continually interrupted, it made the meanings intermittent rather than connected. It seemed that leveled videos and likewise books such as these have wide appeal for the note to parents on the book jacket proclaims it success for readers with phrases like "guaranteed to capture a child's interest" or "putting beginning readers on track," somewhat a quick-fix solution.

\section{Hanging out in the Library}

What do children read in the public library? When asked, Jason, age nine, responded, "I come to play computer games with my friend Josh. We sign up for computer time and we can each play the same game. It is 'funner' than playing by myself." Jason stated that he does not take books out the library, but his mother sometimes selected books for him to borrow. "Instead of taking out books to read, I and Josh do all our reading on the computer games. I like it that way cause there are lots of words and letters on the Internet. Books are too boring."

For Jason, book borrowing was a less valued use of the library. We made specific visits to the local library to question whether activities such as reading books get displaced by computer 
or video gaming. In the multitude of visits (on different days, different hours, and different months over three years), we saw the library as a beehive of activity. The centre of the library was usually packed with patrons jostling for the electronic technologies. Children were checking out videos, five, eight, ten at time, computer users were playing games on the Internet and teens were leafing through the rack of CDs. Some teens were doing research or homework using the computers. Others were using the library as just an evening hangout. Rarely, did we see children in the children's book corner reading or choosing quality children's literature. Books that teachers in Westside Park use as writing models such as Spring Thaw (Schnur, 2000) a poetic text that announces the onset of spring "with a warm wind late at night, sighing through the hemlock trees" and continues through other snapshot images of nature did not seem to be as appealing to young readers. In our conversations with parents, we realized that parents did not view books as passports into other times and places where readers could experience something of what it means to be human. Parents never mentioned selecting books for children that featured varied plots, imaginative writing, memorable characters, or innovative illustrations. Instead, readers seemed to prefer the more simplistic texts with the sameness of the familiar cartoon illustrations such as Barney or Goose Bumps rather than those with literary or artistic merit. We wondered why there was reduced interest in quality texts. Could it be that these books written for children and adolescents by professional authors and illustrators to support reading and writing might be beyond the budgets of Westside parents and not as accessible? Or were these books not sold or marketed within a working class district? Or was it that finding these books in a library can be a challenge as picture storybooks for young readers are catalogued alphabetically rather than by topic making it more tedious for parents to take the time to select books when they are unfamiliar with the names of authors? Or is there a political agenda against the use of real 
books to restrict reading instruction to narrowly conceived, commercially packaged materials (Larson, 2001) that promote recitative answers, a quick-fix solution?

On library visits, we saw adults selecting children's books. Some adults we recognized were preschool teachers and others were parents who came with family book bags and filled them. Shelly, a mother of three, explained why she was a library borrower. "I don't like buying books because I think they're terribly expensive. I love books and the picture books are wonderful, but for the price, it's so horrible. We do once a week at the library for sure." While Ellen, another mother, preferred to have a home library as access to the public library was not as convenient with her working schedule and the sharing of the family car. "Books are so expensive and my daughter outgrows them. I buy used books at garage sales instead and then resell." Renée reminded us that reading books were both expensive and privileging. "I let my children watch Reading Rainbow on television when they were little. If I took a bus to get library books, the bus pass would be over $\$ 50$ per month. What if I had overdue books? I would not be able to afford the fines."

A growing trend in the local library was the sponsorship of literacy programs such as family story hours, workshops on reading to children or how to use the computer. These literacy programs helped to institutionalize ideas about what constitutes what children need to know, how they come to know, what level they need to achieve, and what is an appropriate use of children's out of school time. This situation was true in the technological spaces of the library, too, which pedagogizes educational programs that were advertised to fast track early literacy learning. It became obvious to us that children's literate lives were becoming a script restructured in part by the commodities of the culture and the library was contributing. Reading instruction as delivered 
by leveled books, videos, and computers games had become a commodity packaged to sell or borrow (Shannon \& Goodman, 1994) and in this community it was tailored to the child market.

\section{Goods for Sale}

Mega-corporations such as Disney, Vivendi, and AOL Time Warner with arms into children's publishing houses have made media books as lucrative as possible to attract would be investors to their publicly traded enterprises. As a consequence, media literacy is rapidly replacing book reading (Nodleman \& Reimer, 2003). Book lines based on the electronic game Spiderman, Monsters Inc. or the latest Star Wars movies are hot sellers, and are sold in supermarkets, pharmacies, corner stores, discount stores, or even at gas stations. Successful book licences are distributed in Canada and globally by foreign-owned multinationals. Favorite books like the television-linked Blues Clues relating glib struggles are written and illustrated with formula plots and cartoon caricatures making them illustrated stories rather than children's literature. However, these books are money-spinners ranking at the top of the New York Times best seller's list. While less popular but high-quality Canadian picture storybooks often reflect the cultural mosaic, such as the Ojibwa tale, Morning on the Lake (Waboose, 1993), an ecological journey which conveys to readers a morning glide through still lake waters in a canoe, amid haze and reeds. As literacy educators we were sentimentally attached to books such as these and knew that it reflected the life worlds of many of the urban children who spend time on Northern reserves with extended family. However, we observed that the current trend was the publication of the print book as a secondary form; most books were based on a popular television show, video game, or even as a film not a stand-alone theme. 


\section{Anxious Parents: Available Commodities}

Like the families in Compton-Lilly's research (2003), parents in Westside Park were anxious about their children's reading lives. They had expectations for their children to learn to read quickly and eventually achieve economic success. Many parents had found reading commodities marketed through television, catalogues, the Internet, or on the shelves of the big box store. Not surprisingly, parents told us about their use of web sites such as Disney's Parents' Corner, Between the Lions Tips for Parents, or Jump Start Parents' Café which give families instructional tips on helping their children acquire reading skills while at the same time supplying free printable reading exercises for home drill and practice. Some parents used the fill-in-the-blank printable exercises to test their children on finding a sequence or the right word.

Commercial reading workbooks were also readily available. The interest in these workbooks was huge. Families in Westside Park used the English Smart workbooks sold at the local Superstore or School Zone Get Ready! ${ }^{2}$ workbooks, available at Wal-Mart (workbooks were sold separately or came as grade level bundles with accompanying software), which offered parents "a complete school curriculum sequenced in chunks to help them with the teaching job at home and all the products they might need" (School Zone website). The products emphasized practicing beginning phonics skills with exercises on letter and vowel sounds, rhyming families, letter blends and more. School Zone's web site maintains that they cover the school curriculum in both books and products, but mix the media so that parents can teach a skill like phonics in a game fashion, thus, freeing the parent from giving directions, as the software does that task. Parents saw the advantage of using the computer software along with the workbooks as the computer kept track of the children's progress and rewarded success by opening computer screens or play areas that reinforced the skills taught. "What I like about these computer 
programs is I know for sure what level my children are on. ... I could see progress as my children finished each activity" says Dena. In other words, School Zone redirected home teaching to the computer, which wielded enormous power in shaping culture and promoting dominant ideologies about learning (Giroux, 1999). But do such highly scripted and regulated programs strip parents of their agency and expertise? Perhaps they might.

Technology has changed the socialization of learning literacy. Another prepackaged instructional mode was Leap Pad Games (mentioned by several parents) which sell batteryoperated talking books that are digitalized versions of stories such as Lion King, Toy Story II or Scooby Doo and the Disappearing Doughnuts. Children are encouraged to read independently, but if they become stuck on an unknown word while reading along, they can highlight the text with a magic pen. The pen functions like a hand-held computer mouse pointer while a cartoonlike voice automatically supplies a troublesome word. The child does not need a parent reading coach as the voice does all the work. Prompted reading makes the reading task more imitative rather than interactive. Learners' choices in the program were virtually limited for just a sweep of a highlighting pen opens the door to a system that regulates children thinking, level by level, to a guided mastery of controlled information. Prompted reading may offer learners limited opportunities to develop the powerful and robust word-solving and meaning-constructing strategies that characterize skillful readers.

Most of the major companies that market computer or battery operated literacy games to children, such as Fisher Price, Jump Start, Hooked on Phonics or Lego create their own websites, designed as "branded environments" (Montgomery, 2001) so that the web game becomes the commercial for the endless Edutainment products. Edutainment is the fusion of education and entertainment offerings that invokes a pretense of education and functions to please parents who 
think their children are engaged in literacy learning (Creighton, 1994). Invoking education serves as a means of legitimizing many media pursuits that might otherwise be regarded as overly indulgent fun while relegated to the "back seat" of children's activities is the reading of quality children's books for pleasure. Many Westside Park parents saw merit in using these computers games as teachings tool because they captured children's attention. As one mother explained, "Computer games keep children busy for hours. When my son is at the computer he is truly absorbed and I can get a lot done." Another mother, Lila, recognized its cultural capital. “Computer games are good value. We got our money's worth in Reader Rabbit and Hooked on Phonics as our son learned to read." Lila viewed packaged reading as value added learning. But was it? Learning maybe just learning to recognize words or it may be obtaining a higher score on a reading test but not reading to become a lifelong reader. Lila added that although her son learned to read, "He never picks up a book. I suppose he is reading on the computer and with his X Box games so at least he is doing some reading." The son plays the interactive X box games and as the game producer states "In the living room and via the internet, interactive games will increasingly be a social experience" (Hasboro, 2003). Indeed he is on-line socializing with his friends by writing e-messages about the next strategy in the game and the assault weapons needed for the tasks.

We wondered, what was magical about computer reading games? Parents in Westside Park mentioned using them with their children as a way of "doing their job" that is getting their beginning readers ready for reading. In our own computer play, we observed that Jump Start launches a technologically contoured imaginary universe of colourful graphics, slapstick, and captivating sounds, much like a Disney cartoon. It supports the notion that computer games are designed to present learning level by level as fun. The Jump Start web site states: 
We aren't just here to hand out tools. We're also here to exercise the most important tool of all--the mind. All of our resources include thought-provoking questions and activities that bring learning off the screen and into daily life. (Jump Start, 2002)

The mind is indeed an important tool but do these games nurture internal dialogue, making connections, and creative alternatives or do they simply direct learning? To us, computer reading became a reductionist activity as the games presented seven to ten sentences in a story, which is hardly an immersion in a plot. Jan, a mother of four, praised the games "When my children play computer games, I have evidence that they complete all the reading levels." Another mom, Patience, felt that Jump Start takes the pressure off her as her son's teacher. She stated, "he is mastering a lot of the skills himself." The Jump Start website handily provided evidence of learning as it featured an on-line assessment test where a child could practice a reading skill until mastered. When the child mastered the skill, they could advance to another skill. We questioned whether the games were only a banking system (Freire, 1972), depositing fragments of information which learners were expected to digest and repeat when they get to school rather than depositing a life-long love for reading? Further, Smith (1988) reminds us that children learn to read by reading not by doing worksheets.

Reading is a meaningful activity whereby there is nothing passive or mechanical about it and it is dependent on prior knowledge or expectations of the reader themselves as they engage in a purposeful and rational activity. Reading is not a decoding activity; it is making sense of written language. (p. 2)

Eisner, (1993) points out that technology leads to some "different forms of thinking that leads to different forms of meaning" (p. 6). The Jump Start Phonics games utilized a pastiche of borrowings from the media culture while we found that its printable worksheets drill children on 
discrete sound-symbol relationships in order for them to win merit badges. In this kind of packaged reading program, words were grouped on the basis of their linguistic patterns often introducing very young learners to abstract words presented in isolation which was a giant step backward in how children learn literacy in meaningful contexts (Goodman, 1994; Harste, 1990; Smith, 1999). For example, the program followed a consonant-vowel-consonant pattern, a gaming sequence that presented short abstract words such as jaw, mob, peg, bet, sob, or those which added a silent e to teach unrelated words without a context as in cube and ride. Are these decontextualized words meaningful to young children? Probably not. But, they sell as they adopt the pedagogy of Reading First, the American reading initiative that sees reading as dividing the nation into two, one that reads and one that does not, one that dreams and one that does not. The measurement of reading is with standardized tests focused on linguistic skills. School Zone and English Smart reading packages are aligned with this approach. Both are created for other markets but under the banner of globalization they have expanded their sales to Canada $^{1}$ and they have wide market appeal. A trip through the aisles of the local stores exposed Westside Park parents to only one menu of products, which gave reading commodities positions of power that was bolstered by business savvy and the need for continued commercialization.

\section{Clicking the Mouse vs. Turning the Pages}

What were children doing when they play reading games on the computer? When observing children playing computer games, we noticed a child playing Reading Blaster 7-8 in an episode where Blaster was trying to run away from a volcano before it blew up. “Jump Blaster! Jump! Get out, get out or you will be blown up to a zillion pieces, " yelled Peter to the computer! There was an animated sequence and Peter clicked the mouse on objects all over the screen checking out what made noise and what moved. Actions were frenzied as Peter looked for the hypermedia 
links on the screen that followed a new pathway in the story plot to produce an interactive media experience (hypermedia combines hypertext, texts linked together by multilinear nodes and multimedia, e.g., animation, art, audio, text). Or were these links diversions? Peter spent considerable time clicking on objects on one screen before moving onto the next screen. Was this the next page in an unfolding story? Probably not, for if Peter wanted to a read a story he wouldn't be "gaming" on the screen. What seemed to be happening was that when young readers like Peter play a captioned video game, the story became fragmented. With this type of textual experience, children become immersed in associative thinking rather than sequential thinking, which is the underlying structure of both story-making and story-writing for beginning readers and writers. According to Burbules (1998), "The conventions of reading, like those of writing, have grown out of the structures of sentences flowing into paragraphs, paragraphs flowing into pages, pages followed by other pages" (p. 106) which is what teachers of reading and writing expect their students to know. In this way, media reading supplements rather than replaces more familiar linear structures.

Embedded in Peter's computer game philosophy, reading appeared to be learning language skills mechanically rather than reading as an interactive process that developed problem solving, critical and creative thinking, hypothesizing, independent thought, or weighing alternatives. While some parents that we interviewed insisted that games like Jump Start teach children to read one mother, Doris, believed, "Jump Start is a lot of fluff. It is just a way to teach computer skills. The only thing they learn is how to click and change the windows. They don't remember the story 'cause there really is not one."

What messages do these computer-learning games give children? Perhaps, it was the message that Jason and Peter knew; reading should be amusement. This view might be turning 
the reader away from the interpersonal relations of family life and the experiences of growing up with parents as reading coaches and mentors. Read-aloud picture storybooks usually invite indepth reading such as in Jane Yolen's Owl Moon (1987) which illustrates that one of the greatest charms of children is their ability to view a simple activity as a magical adventure such as a walk through the woods on a late night. The charm rises from its simplicity. "It was late one winter night, long past my bedtime, when Pa and I went owling." Father and daughter walk through the woods on a journey with nothing but hope and each other. Reading is intended to open possibilities to think, connect, and imagine in new ways. Huck, Hepler, and Hickman (1987) hold that when children think thoughtfully about a story and the lives of others, "they may begin to filter out some meaning for their own lives" (p. 466). We realized that computer games were an implicit bracketing of these points of contact with reality and the social worlds that we associate with children's learning experiences. There is a concern that although computers were powerful tools they also could isolate young children physically from direct experiences with the natural world and emotionally from socially interactions with nurturing others. As Doris explained,

I know it is important that children learn to read before they come to school. I think computer reading programs like Jump Start are ok, perhaps, as a treat but it does not replace a book. You don't have the feel. You don't have the cuddle of three of us sitting down in the Easy-boy chair and reading a book. You have a computer where one's playing and one's watching and Mom and Dad are tuned out. So in our house, the computer is all about privileges. We don't use it as a learning tool. We use it as a reward. If you have done well in school, yes, you can go play... at the computer. 
As educators, we were constantly reminding ourselves that language learning is social (Vygotsky, 1986) and is not learned because children want to talk, read, or write about language. Children learn language because they want to talk, read, and write about their world, especially with their parents and others in the community. One of the teachers at Westside Park agreed when she mentioned that many children lack that "knee time or lap time that children used to get a lot more before we had 24-hour kid's TV channel and other media." Another teacher thought that children "are missing a lot of those early literacy experiences, so that means that they do not have the language to write." Her statement resonated with our findings for media reshapes literacy practices in profound yet subtle and unexpected ways.

Kline (1993) cautions about market goods that substitute for and displace the traditional patterns of family relations when he states:

Something is missing from childhood, ...when we give a child a musical tape of children's songs because we don't have time to sing to or with them;.... when we let them watch fantasies on TV, without reading to them or exposing them to the intimacy of personal storytelling; when we give a child Nintendo, but fail to teach them the finger games or craft skills (knitting, carpentry, gardening) that have been traditions within our families. (p. 13) If this is so then the true teachers of children were not parents or schoolteachers but filmmakers, video creators, advertising executives, and pop culture purveyors who are packaging profitable literacy goods. Yet, the academic commentaries about childhood seldom query the consumer markets as part of a matrix of contemporary socialization or take into consideration how children learn these roles, attitudes, and attachments that reinforce the consumer culture. It might be less insightful to explain what children are not reading as a problem with the child rather than recognizing the precipitating role of the media culture in their lives. 


\section{Parents Taking Charge}

Many Westside Park parents were concerned by the overuse of television and videos with young children. Listening to the voices of parents, we found that although they often have differing viewpoints, TV was an issue facing parents as parents relate their dilemmas.

Catherine stated:

My kids don't watch very much TV so they have to find ways to prolong play so that they can entertain themselves. As a mother, I am there to make sure that they have age-appropriate play and make resources like blocks, picture books, art materials, musical instruments, or bicycles available.

Ellen parented differently with her daughter, Amanda, than she did with her older children who encountered early difficulties in reading.

We have family restrictions on television. She likes nature shows especially if they are about animals. She watches the Discovery and Nature channels. Either her Dad or I will ask talk to her about what she views and then we often look for books at garage sales on those topics.

Grace, an immigrant mother, expressed mixed feelings about the media suitable activities. I don't want my children to play video or computer games and watch a lot of TV. When they do, they often spend hours in front of a screen. But, if I don't allow them to do the things that other kids do then they will be different and be left out.

\section{Lessons Learned}

The increased value given to natural learning and authentic settings for research helped us see over time the complexity of children's literacy communities. Sometimes children's 
connections with school literacy were resonating, while at other times the connections were oppositional. As researchers, we saw how technological literacies were important for children, and how these literacies were learned informally without schools thus transforming the spatial, temporal and social contexts of learning. However, we have the same critique of many of these technological literacies as we did of basal reading programs two decades ago when we saw reading presented as lockstep content to be mastered rather than a socially constructive practice. Technological literacies need to rethink the transmission model of learning and move toward a constructivist process that fosters learning by doing.

In our analysis of what constitutes community literacy, we saw Westside Park as a built landscape sharing a common dialect (Bakhtin, 1981) or layer of discourse that sutured children to similar social beliefs and values. Continually, children moved in and out of layers of community and layers of literacy networks organized and restructured by representations tiedinto virtual spaces. Children's consumption held an ambiguous position between domestic space, public space and the "tie-in" commodities that make these meanings concrete through purchase and ownership (Seiter, 1997, p. 300). In the past, children's culture was produced by children and distributed through child-to-child contact (Opie \& Opie, 1969). Now in a globalized world, children's culture is linked with a community built by corporations via electronic technologies for the purpose of inducing children to consume. As Kincheloe (1997) observes, advertisers connect children's culture to their representations as they carefully subvert middle class parenting desires for achievement and quality time (p. 256), something that held true for the working class parents in Westside Park, too. Luke (1997) believes that children are now growing up "with the electronic, symbolic, commodity, and ideological signification system of popular culture" (p. 20). The real time and social practices constructed around watching TV, shopping at the mall, and constructing an identity through media affiliation are simulated 
experiences that have limited concrete referents in the real world. Only purchase and ownership can make these mass marketed symbolic meanings concrete (pp. 22-23).

Our literacy work was informed by the question of who get access to which technologies and practices of representation in the community. Schools and literacy education were active participants in the traditional fractures of culture and class. What seemed certain was that visibly displayed levels of literate practice become requisite forms of cultural capital, a necessary bridging for entry into institutional and public life. In a text-saturated culture, not having access to particular context-sensitive reading and writing practices that school value might systematically deny a learner entry into linguistic and literate markets. The process of becoming literate in school then entails the appropriation of cultural, textual forms, and practices that were more typical of institutional life. The challenge then is not just one of equity of access to such technologies and institutions, but also of the possibilities of using discourse and literacy to reinvent institutions, to critique and reform the rules for the conversion of cultural and textual capital in communities and workplaces and to explore the possibilities of heteroglossic social contracts (Bakhtin, 1981) and hybrid cultural actions. The question not answered in this study is what else can we do with technological literacies other than launch literacy learning as a commodified program? Can we as educators interrupt that practice?

Luke (1997) reminds us that TV and other technologies cannot be ignored by schooling but must be treated seriously as social practice and a social text (p. 20). Hilton (1996) and Dyson (1997) argue that schools need to foster ways to listen and to value the many literacies and texts, including media, which help to construct children's identities in and outside of school. The computer had an incredible impact upon the children as they learned to read a variety of formats and use new technologies for the rapid retrieval of information, for writing their thoughts, for 
communicating with others, and for creating programs of their own. The new technological literacies supplemented rather than replaced oral and print literacies.

A shared set of intertextual references to the kid networks provides a common pool of experience for literacy conversation and representation. Instead of ignoring the texts of everyday life, we call for providing young learners with a toolkit--not just a pencil, joystick, or a mouse-but critical dialogue so that they can interrogate texts, that is, talk about what they see and hear. Electronic texts can be the literacy bridge to raise issues of power, justice, respect, privilege, or gender in the classroom. In this way, children's social interest in literacy heightens as they reflect critically on the multiple messages they are viewing (Luke, 1997, p. 33).

As children become multi literate and multi modal, they will still need reading print for a wide range of social practices and they will need books for pleasure. Hopefully, books will continue to live and flourish and children of tomorrow will still be able to savor holding a book in their hand and turning its pages with anticipation during the unfolding of a story.

Ultimately, we hope that this research on community literacy within the landscapes of young readers and writers can inform school practices as theory and application interface. Information gathered by such research might be useful in a society grappling with the reality that increasingly technology is changing literacy practices globally.

\section{References}

Bakhtin, M. M. (1981). The dialogical imagination. Austin, TX: University of Texas Press. 
Barton, D., \& Hamilton, M. (1998). Local literacies: Reading and writing in one community. New York: Routledge.

Bourdieu, P. (1986). The forms of capital. In J. Richardson (Ed.), The handbook of theory and research for the sociology of education (pp. 241-248). Westport, CT: Greenwood Press.

Burbules, N. C. (1998). Rhetorics of the web: Hyperreading and critical literacy. In I. Snyder (Ed.), Page to screen: Taking literacy into the electronic era (pp. 102-122). New York: Routledge.

Compton-Lilly, C. (2003). Reading families: The literate lives of urban children. New York: Teachers College Press.

Crawford, M. (1992). The world in a shopping mall. In M. Sorkin (Ed.), Variations on a theme park (pp. 3-30). New York: Hill \& Wang.

Creighton, M. R. (1994). "Edutaining" children: Consumer and gender socialization in Japanese marketing. Ethnology, 33, 35-52.

Dyson, A. H. (1997). Writing superheros: Contemporary childhood, popular culture, and classroom literacy. New York: Teachers College Press.

Eisner, E. (1993). Forms of understanding and the future of educational research. Educational Researcher, 22, 5-11.

Furman, G. C. (1998). Postmodernism and community in schools: Unraveling the paradox. Educational Administration Quarterly, 34 (3), 298-328.

Freire, P. (1972). Pedagogy of the oppressed. Harmondsworth, UK: Penguin.

Giroux, H.A. (1999). The mouse that roared. Lanham, MD: Rowman \& Littlefield Publishers.

Goodman, K. S. (1994). Reading, writing and written texts: A transactional sociopsycholinguistic view. In R. R. Ruddell, M. R. Ruddell, \& H. Singer (Eds.), 
Theoretical models and processes of reading (4th ed., pp. 1093-1130). Newark, DE: International Reading Association.

Hasboro Interactive. Retrieved June 06, 2003 from the World Wide Web: Web http://www.hasbro-interactive.com.

Harste, J. (1990). Jerry Harste speaks on reading and writing. The Reading Teacher, 43, 116120.

Heath. S. B. (1983). Way with words. Cambridge, MA: Cambridge University Press.

Hicks, D. (2002). Reading lives: Working-class children and literacy learning. New York: Teachers College Press.

Hilton, M. (1996). Manufacturing make-believe: Notes on the toy and media industry for children. In M. Hilton (Ed.). Potent fictions: Children's literacy and the challenges of popular culture (pp. 19-46). New York: Routledge.

Huck, C., Hepler, S., \& Hickman, J. (1987). Children's literature in the elementary school (5th ed.). Toronto: Holt, Reinhart, and Winston.

Jump Start. (2002). Parents Café. Retrieved June 23, 2002 from the World Wide Web: Web http://www.education.com/jumpstart/.

Kincheloe, J. L. (1997). McDonald's, power, and children: Ronald McDonald (aka Ray Kroc) does it all for you. In S. R. Steinberg \& J.L. Kincheloe, (Eds.), Kinder-Culture: The construction of childhood (pp. 249-266). Boulder, CO: Westview Press.

Kline, S. (1993). Out of the garden: Toys and children's culture in the age of TV marketing. Toronto: Garamond Press.

Larson, J. (2001). Literacy as snake oil: Beyond the quick fix. New York: Peter Lang. Lave, J., \& Wenger, E. (1999). Situated learning: Legitimate peripheral participation. Cambridge, UK: Cambridge University Press. 
Luke, C. (1997). Media literacy and cultural studies. In S. Muspratt, A. Luke, \& P. Freebody (Eds.), Constructing critical literacies: Teaching and learning textual practice (pp. 1949). Cresskill, NJ: Hampton Press.

Luke, A., \& Freebody, P. (1997). Shaping the social practice of reading. In S. Muspratt, A. Luke, \& P. Freebody (Eds.), Constructing critical literacies: Teaching and learning textual practice (pp. 185-225). Cresskill, NJ: Hampton Press.

Moll, L. C. (1992). Literacy research in community and classrooms. In R. Beach, J. L. Green, J. L. Kamil, \& T. Shanahan (Eds.), Multidisciplinary perspectives on literacy research (pp. 211-244).Urbana, IL: National Council of Teachers of English.

Moje, E. B. (2000). Critical issues: Circles of kinship, friendship, position, and power: Examining the community in community-based literacy research. Journal of Literacy Research, 32 (1), 77-112.

Montgomery, K. (2001). Digital kids: The new on-line children's consumer culture. In D. G. Singer \& J. L. Singer (Eds.), Handbook of children and the media (pp. 635-651). Thousand Oaks, CA: Sage Publications.

Nespor, J. (1997). Tangled up in school. Politics, space, bodies, and signs in the educational process. Mahwah, NJ: Lawrence Erlbaum Associates.

Neuman, S. B., \& Celano, D. (2001). Access to print in low-incomes and middle-income communities: An ecological study of four neighborhoods. Reading Research Quarterly, $36(1), 8-26$.

Nodelman, P., \& Reimer, M. (2003). The pleasures of children's literature (3rd ed.). Toronto: Allyn and Bacon.

Opie, I., \& Opie, P. (1969). Children's games in street and playground. Oxford, UK: Clarendon Press. 
Petersen, R. L., \& Eeds, M. (1990). Grand conversations: Literature groups in action. Richmond Hill, ON: Scholastic.

Postman, N. (1982). The disappearance of childhood. New York: Delacorte Press.

Purcell-Gates, V. (1997). Other people's words: The cycle of low literacy. Cambridge, MA: Harvard University Press.

School Zone Curriculum. What is the school zone. Retrieved February 3, 2002 from the World Wide Web: http://www.schoolzone.com/html/what_is_the_school_zone_curric.html. Schnur, S. (2000) Spring thaw. Illustrated by Stacey Shuett. New York: Viking.

Schuster, M. (1977) The library centered approach to learning. Palm Springs, CA: ETC Publications.

Scott-Jones, D. (1995). Parent-child interactions and school achievement. In B. A. Ryan, G. R. Adams, T.P., Gullotta, P. R., Weissberg, \& R. L. Hampton (Eds), The family school connection: Theory, research and practice (pp. 75-93). Thousand Oaks, CA: Sage Publications.

Seiter, E. (1993). Sold separately: Children and parents in the consumer culture. New Brunswick, NJ: Rutgers University Press.

Shannon, P., \& Goodman, K. (1994). Basal readers: A second look. Katonah, NY: Richard C. Owens Publishing, Inc.

Smith, F. (1999). Why systematic phonics and phonemic awareness instruction constitute an educational hazard. Language Arts, 77 (2), 150-155.

Smith, F. (1988). Understanding reading: A psycholinguistic analysis of reading and learning to read. Hillsdale, NJ: Lawrence Erlbaum.

Street, B. (1984). Literacy in theory and practice. Cambridge, UK: Cambridge University Press. 
Street, B. (1995). Social literacies: Critical approaches to literacy in development, ethnography and education. New York: Longman.

Street, J.C., \& Street, B. (1991). The schooling of literacy. In D. Barton \& R. Ivanic (Eds.), Writing in the community (pp. 106-131). Thousand Oaks, CA: Sage.

Taylor, D. (1983). Family literacy: Young children learning to read and write. Exeter, NH: Heinemann Educational Books.

Taylor, D., \& Dorsey-Gaines, C. (1988) Growing up literate: Learning from inner-city families. Portsmouth, NH: Heinemann Educational Books.

Valdés, G. (1996). Con Respeto: Bridging the distances between culturally diverse families and schools. New York, NY: Teachers College.

Vygotsky, L. S. (1986). Thought and language (A. Kozulin, Ed.). Cambridge, MA: MIT Press.

Waboose, J. B. (1997). Morning on the lake. Illustrated by K.Reczuch. Toronto: Kids Can Press.

Wason-Ellam, L. (2001). Living against the wind: Pathways chosen by Chinese immigrants, Canadian Ethnic Studies, 33 (1), 1-39.

Yolen, J. (1987). Own moon. Illustrated by John Schoenherr. New York: Philomel Books.

Zemach, M. (1976) It could always be worse: A Yiddish folk tale. New York: Farrar, Straus and Giroux.

Notes 
${ }^{1}$ The study was funded by the Social Science Humanities Research Council of Canada.

${ }^{2}$ School Zone, a US publisher, presents a sequential, fully integrated curriculum for the teacher at home and marketed on a mass scale. School Zone is the original workbook company. English Smart is published by Popular Books Canada, a subsidiary of Popular World Holdings, Singapore, who set up educational materials to serve the highly educated pool of Hong Kong immigrants in Canada. 